\title{
Political Constraints and the Limited Effect of Electoral System Change on Personal Vote-Seeking in Hungary
}

\author{
Zsófia Papp \\ Centre for Social Sciences, Hungarian Academy of Sciences, Budapest, \\ Hungary
}

\author{
Burtejin Zorigt \\ Centre for Social Sciences, Hungarian Academy of Sciences, Budapest, Hungary; \\ Central European University, Budapest, Hungary
}

\begin{abstract}
This article aims at capturing how the recent changes in Hungary's mixed-member electoral system altered the candidates' personal vote-seeking strategies. Based on the literature, one might expect that strengthening the role of the Single-Member District (SMD) tier increases the incentives for personalisation. By utilizing the data from two consecutive waves of the Comparative Candidate Survey, we show that contrary to these expectations the average level of campaign personalisation decreased from 2010 to 2014. Semi-structured interviews with nine campaign staff members confirm that the political constraints were more important in determining campaign strategies than the institutional setting. Our findings challenge the dominating effect of electoral rules on personal vote-seeking.
\end{abstract}

Keywords: campaign; mixed electoral system; personalisation; Hungary; candidates; comparative candidate survey; personal vote-seeking

\section{Introduction}

It has been extensively argued that a certain proportion of the candidates' vote share is independent from party affiliation, fixed voter characteristics, and economic trends. ${ }^{1}$ This fraction of the vote is called the personal vote and it originates in the qualifications, abilities, personal characteristics, and the record of the candidates. ${ }^{2}$ To appeal to the personal vote, candidates must advertise these features and increase visibility by organising personalised campaigns. Nevertheless, the utility of such campaigns is a function of the electoral rules under which Members of Parliament (MPs) are elected.

There is a difference between electoral systems in terms of how much incentive they create for seeking a personal vote. ${ }^{3}$ Electoral formula, ${ }^{4}$ ballot structure, ${ }^{5}$ and district magnitude ${ }^{6}$ are all demonstrated to affect personal vote-seeking. Focusing on 
the electoral formula, while Single-Member Districts (SMDs) create incentives to personalise through a clear linkage of accountability and the voters' ability to choose between candidates, multi-member districts leave space for personalisation only if party lists are flexible. In a mixed-member system, a considerable percentage of the MPs are elected on the SMD tier. Thus, for a relatively high percentage of the candidates, campaign personalisation is a viable strategy to attract extra votes. Intuitively, the more dominant the role of the SMD tier is in getting elected, the larger the incentives to seek a personal vote.

This article focuses on the effect of electoral rules on campaign personalisation in the context of a country applying mixed electoral rules. Recent changes in the Hungarian electoral system provide us with an opportunity to test how strong the effect of the SMD tier actually is. We investigate whether-as the literature would suggest-the increasing significance of the SMD tier makes individual campaigns more personalised. Based on an analysis of two Hungarian rounds of the Comparative Candidates Survey from 2010 and 2014, and a series of semi-structured interviews, we conclude that political constraints render the effect of electoral system change limited.

The study of campaign personalisation is paramount for at least two reasons. First, in order to have a solid electoral connection between the representatives and represented, the representatives need to be seen. Personalised campaigning increases visibility and thus fosters the accountability of individual legislators. Second, as some have already suggested, ${ }^{7}$ personalised campaigns might serve as indicators of how candidates will behave in parliament when elected. Legislators with more personalised campaigns may be more inclined to constituency orientation and voting against the party if the party's opinion conflicts with constituent interests. Therefore, personalised campaigns help voters in their quest to elect "good" representatives 8 and thus increase the quality of representation.

The structure of the article is as follows. First, we give a brief insight into the literature on the relationship between electoral rules and personalisation. It is followed by an introduction to the recent changes in the Hungarian electoral system, where we formulate expectations derived from the literature and make a counterargument based on political context. The third section introduces our data and variables with a short description of the anticipated variable effects. Fourth, multivariate models are built to capture the change in campaign personalisation between 2010 and 2014, which is complemented by a series of interviews with campaign experts and analysts. Finally, we summarise the results in the last section.

\section{Theoretical Framework}

Recent research on the connection between electoral rules and campaign personalisation is vast. ${ }^{9}$ Authors agree that candidate-centred electoral rules encourage campaign personalisation, while party-centeredness pushes the focus of the 
campaign toward the party end of the continuum. In their oft-cited article, Carey and Shugart ranked the different electoral systems on the basis of the incentives they offer to cultivate the personal vote. ${ }^{10}$ Three major factors were taken into account to assess the effects of the various system variants: electoral formula, ballot structure, and district magnitude. From these three aspects we focus on the first, which distinguishes between majoritarian and Proportional Representation (PR) systems.

The differences between the two types of electoral system are related to their application of single-member versus multi-member constituencies. While SMDs create a stronger linkage of accountability by setting clear responsibility for the different (positive and negative) outcomes, ${ }^{11}$ multi-member districts increase the incentives to free-ride on the achievements of fellow MPs by reason of the territorial overlap between legislators. ${ }^{12}$ In such systems, legislators are more accountable to the party leadership than to the electorate, ${ }^{13}$ which essentially makes the contest for re-election a fight for higher positions on the party list. ${ }^{14}$

Furthermore, rules and practices of candidate selection affect personalisation substantially. As argued by several researchers, selection strategies are the major determinants of whether the electoral system truly rewards or punishes personalisation. ${ }^{15}$ As a general rule, the more decentralised the nomination process, the greater the incentives for the candidates to personalise. ${ }^{16}$ Centralised and exclusive candidate selection might even overwrite the effect of electoral rules on campaign personalisation. In countries where the party centre has exclusive control over nomination, and the proportion of safe seats is large, the competition for re-election becomes a struggle for re-selection. Thus, it might be logical to expect that selected candidates are more loyal to the party than those who were not chosen. Therefore, party-centred campaigning will also be more pronounced even under candidate-centred electoral rules.

The concern over the effect of candidate selection masking the effect of the electoral system is also valid for Hungary, where parties - especially those having a realistic chance at winning mandates on the SMD tier ${ }^{17}$ — centralise candidate selection. The question here is whether there is any place for personal vote-seeking in a party with centralised (and exclusive) candidate selection procedures. Oddly, the answer is yes. Even when there is no place for the voters to choose between candidates from the same party, the party's right to nominate a candidate might play a crucial role in increasing the incentives to personal vote cultivation. ${ }^{18}$ Cain et al. point to possible party strategies to attract votes that encourage the nomination of locally well-known candidates to the party lists. ${ }^{19}$ Curtice and Shively, and Gallagher and Holliday also agree that if voters value candidates who actively engage in constituency service, district representation, and ombudsman-like activities, then parties have an incentive to give priority to personal vote-seeking instead of building only on party appeal. ${ }^{20}$ Thus, personalisation may not only be a tool of individualisation for candidates but also a party strategy. Although centralised candidate selection shifts candidates to pursue party-oriented campaigns, it does not necessarily enforce party-centeredness in the case of candidates with high visibility. ${ }^{21}$ 
As we have seen, there is a consensus that majoritarian systems support personalised campaigns. The rules of PR on the other hand, especially with closed ballots, strengthen the party aspect of campaigning. The question is whether in systems that incorporate both SMDs and multi-member districts, candidate or party centeredness will prevail. It can be argued that if success in the SMD competition is key for winning the election, parties should mobilise resources and adopt strategies that increase the number of votes on the SMD tier. Assuming that party popularity in the district is given, the way to increase the SMD vote share is to appeal to personal vote by strengthening candidate visibility through campaigning. Based on the literature, we test whether or not the increasing importance of the SMD tier makes individual campaigns more personalised.

The changes in the Hungarian electoral rules in 2011 offer a great opportunity to observe the effect of the majoritarian shift in a mixed-member electoral system. In the next section, we argue that recent changes in the electoral system strengthen the SMD tier, and thus should increase incentives to personalise. Additionally, taking into account the political context, we make a counterargument that limits the effect of electoral rules on personalisation.

\section{The Hungarian Case}

Post-transition Hungary has a mixed-member majority system with partial compensation. ${ }^{22}$ Electoral rules from 1990 to 2010 were largely the same, with a few modifications in 1994..$^{23}$ The first considerable change was administered in 2011, and pushed the system closer to the majoritarian end of the majoritarian versus PR continuum. In that respect, Hungary is a peculiar case within the context of Eastern Europe. In the 1990s, the majority of Eastern European countries adopted proportional representation as the electoral formula. Although some have tried to replace PR with majoritarian electoral rules applying single-member districts, none have been completely successful. Romania, for example, switched from PR to mixed electoral rules, but the system has remained fairly proportional. The main reason for the general reluctance to introduce majoritarian rules is argued to be that consensus democracy itself is not compatible with majoritarian voting systems. ${ }^{24}$

From 1990 to 2010, 386 representatives were elected in three tiers. On the SMD tier, 176 mandates were distributed in a majority run-off system: absolute majority in the first round, and first-past-the-post (FPTP) in the second. In the second round, the first three candidates from the first round and everyone who reached the 15 per cent mark were invited to compete for the seat. On the regional list tier, a maximum of 152 mandates were available from twenty regions (nineteen counties and the capital city). Seats were allocated by the PR principle applying the Hagenbach-Bischoff formula. Mandates not distributed on this level pooled to the national list tier, where at least fifty-eight legislators were elected. Party lists on the regional and national 
Table 1

Major Changes in Electoral Rules in 2011

\begin{tabular}{|c|c|}
\hline 2010 elections & 2014 elections \\
\hline 176 SMD mandates out of 386 seats in parliament & 106 SMD mandates out of 199 seats in parliament \\
\hline Three tiers (SMD, regional, national) & Two tiers (SMD, national) \\
\hline $\begin{array}{l}\text { Non-utilized votes on the first tier: votes cast for } \\
\text { the losing candidates (losers' compensation) }\end{array}$ & $\begin{array}{l}\text { Non-utilized votes on the first tier: votes not } \\
\text { essential to get elected (winners' compensation) }\end{array}$ \\
\hline Two rounds & One round \\
\hline Voters do not vote for the national party lists & Voters vote for the national party lists \\
\hline
\end{tabular}

tiers were closed. Although there were three electoral tiers, voters could cast only two votes: one for an SMD candidate and one for a regional party list. The national level vote count equals the sum of votes cast for the losing candidates in the SMDs and the votes that were not essential to win mandates on the regional list tier. This pool of votes from the lower levels to the national tier balances the disproportionalities created by the SMD tier. Mandates on the national list tier are allocated using the d'Hondt method. Furthermore, only parties that reached 5 per cent of all the nationally aggregated regional list votes were entitled to mandates from the list tiers (both regional and national). Parties not reaching the 5 per cent threshold may only keep their SMD seats.

In 2011, new electoral rules were adopted, and the logic of political competition was substantially changed. This was the first and (to date) the only change to the electoral system that influenced the transformation of votes into mandates. The new law radically decreased the number of legislators from 386 to 199. Redistricting resulted in 106 SMDs, in which MPs are elected by the rules of FPTP in one electoral round. The remaining 93 seats are distributed on the national level. The party list votes come from two sources. First, voters cast their votes for one of the competing party lists. Second, votes not necessary for election on the SMD level are pooled to the national tier. This also includes the votes of winning candidates, in which case the vote difference between the first two candidates in the SMD minus 1 adds to the national level vote count. As to the ballot structure, party lists remain closed. The level of the electoral threshold also stays the same. Table 1 summarises the changes in the electoral system.

Naturally, changes in the electoral rules alter the logic of political competition. They influence party system fragmentation, coalition strategies, the proportionality of parliamentary representation, the local orientation of legislators as well as campaign strategies just to name a few. In the following, we discuss changes that directly influence how parties and individual candidates might perceive the benefits 
of personalisation, and argue that the changes encourage candidates to pursue more personalised campaigns.

First and foremost, while in 2010, 45.6 per cent of MPs were elected on the SMD tier, in 2014, this percentage increased to 53.2. Therefore, the SMD competition became even more important for both the parties and the candidates. Massive electoral success in the constituencies makes final victory very likely. Furthermore, for the individual candidates, a larger proportion of MPs elected in SMDs increases the relative value of the constituencies in getting (re-)elected. Thus, given the connection between SMDs and campaign personalisation, it can be expected that personalisation will also be more apparent.

Second, losing one of the list tiers further increases the importance of the SMD tier in the quest for election. Whereas in 2010 candidates had three shots at winning a mandate, in 2014 they only had two. In 2010 SMD candidates were usually placed high on the regional party lists, while top positions on the national list went to national-level party leaders. Thus, unsuccessful SMD candidates were elected from the regional lists with a greater probability than from the national tier. The implementation of the new electoral rules hardly changes the logic of how the national party lists are constructed: party leaders will still select themselves to the top positions. There is also no reason to think that the number of party leaders decreased between the two elections. This means that the structure of the national list will remain the same. Nevertheless, in 2010, regional party lists could absorb the majority of losing SMD candidates, who then did not burden the national party lists. In 2014, however, although the national list tier was longer than in 2010, it was only long enough to secure the seats for a limited number of SMD losers. Thus the "safety net" under the candidates is not that "safe" anymore after introducing new electoral rules resulting in a fiercer competition on the first tier. The growing importance of winning the SMD seat motivates candidates to gain extra votes by expanding the party campaign with traits of personalisation.

Third, losers' compensation on the list tier in 2010 encouraged underdogs to gather extra votes through personalisation and then pool their votes to the national level, where they could boost the party vote count. In 2014, winners no longer had to give up extra votes either. Winners' compensation ensures that votes not needed to get elected will also increase the party votes. In 2014, both prospective winners ${ }^{25}$ and losers were interested in pursuing personal vote, while in 2010 only losers were. Thus, campaign personalisation is expected to increase from 2010 to 2014.

The literature on the effects of electoral rules often neglects the context in which the effects of rules are shaped. To evaluate the effects of electoral system change, one should look at the political climate and power relations in which these changes take place. During the electoral system change, Hungary faced a political situation that was rather peculiar taken the whole post-transition period into account. By 2002, the logic of the electoral rules created a two-block system with two big and several small parties competing in two large party blocks. The left was led by MSZP ${ }^{26}$ that - together 
with SZDSZ27 — governed in 1994-1998, 2002-2006, and 2006-2010. Fidesz ${ }^{28}$ was MSZP's counterpart on the right leading the government coalition in 1998-2002. The party system became more concentrated and the role of winning in the SMDs was said to become more and more important for winning elections. The competition of the two blocks was fairly balanced until 2010 when the two-block system was replaced with one-party hegemony. ${ }^{29}$ The popularity of MSZP started to decline after the infamous speech of Prime Minister Ferenc Gyurcsány was leaked in September 2006, in which he admitted that they had lied to the citizens and that they had not done anything significant during their previous term between 2002 and 2006.

While polls placed the two main parties neck and neck (35-35 per cent) just before the 2006 elections, by 2010 MSZP had fallen below 15 per cent, whereas Fidesz managed to keep its popularity at 35 per cent. The difference between the two parties was even more significant within the group of "certain" voters: Fidesz scored 60 per cent while MSZP hardly reached 20 per cent. ${ }^{30}$ The victory of Fidesz seemed certain, and only one question remained: would Fidesz reach a two-thirds majority in parliament or not. Power relations between the 2014 elections were quite similar. Fidesz had about 50 per cent of votes within the group of "certain" voters, whereas the left-wing coalition reached only 20-25 per cent. ${ }^{31}$ The victory of Fidesz-KDNP was again expected by all competing parties, which was further cemented by the new election law of 2011. Several have argued that the new electoral rules clearly benefit Fidesz, especially with the configuration of the new constituency boundaries, ${ }^{32}$ and allowing nonresident citizens to vote. ${ }^{33}$ Additionally, as Fidesz was expected to win the overwhelming majority of the SMD seats, "winner's compensation" mainly served the interests of the governing party.

Based on the above, the changes in the electoral rules shifted the system in a more majoritarian direction, and at the same time became a tool to strengthen the government's position. Election results were highly predictable, with Fidesz harvesting the SMDs and the opposition losing its former strongholds. Under such circumstances, parties may want to refrain from the costly business of campaign personalisation. Fidesz dominates the districts, while parties with no hope in the constituencies may want to focus on strengthening their party image. With this in mind, even if the electoral rules favoured increased personalisation, political context might have stepped in to redirect candidate-centred campaign to party-centeredness. To solve this puzzle, we build upon the data set of the Comparative Candidate Survey and expert interviews with campaign managers, strategists, and analysts.

\section{Research Design}

The analysis first utilises the data of the Comparative Candidates Survey collected in 2010 and 2014 shortly after the elections. The data constitute an unbalanced panel, with 73 candidates participating in both waves. ${ }^{34}$ MPs were randomly selected for face-to-face interviews. Unsuccessful candidates were 
Figure 1

The Kernel density of campaign personalisation in 2010 and 2014

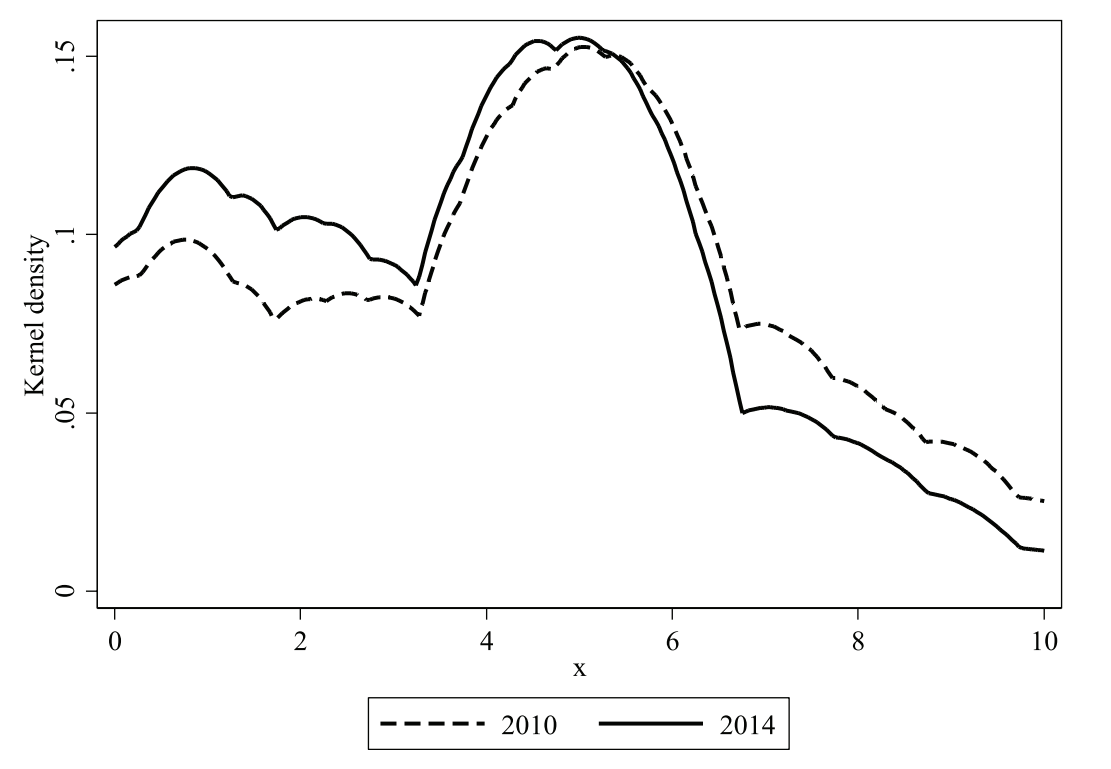

contacted with the online version of the questionnaire. As a result, the sample contains 205 (53.8 per cent of the 2010 sample) MPs in 2010, and 88 (38.4 per cent of the 2014 sample) in $2014 .{ }^{35}$ Nevertheless, we are not aware of any circumstance that would make non-response not random in the group of unsuccessful candidates. Although only a part of the sample may be considered random, we apply the standard tests of significance to establish the effect of system change on campaign personalisation. ${ }^{36}$

We apply the concept of campaign norms by Zittel and Gschwend. ${ }^{37}$ We asked respondents to place the main goal of their campaigns on an 11-point scale, with low values indicating party-centeredness, and large values indicating candidatecenteredness. In other words, the larger the value of this variable, the more personalised the individual candidates' campaigns. Figure 1 shows the Kernel density estimation $^{38}$ of the campaign norms variable at the two elections. From 2010 to 2014, the graph shifted to the left (i.e., the party-centred end of the scale), which is not in line with the expectations of the literature.

We also looked at the connection of our dependent variable to the usage of various campaign tools to see if it indeed measures campaign personalisation. These campaign tools were (1) personal campaign posters, (2) personal newspaper ads, (3) personal spots in radio/TV/cinemas, (4) personal flyers or other (give-away) campaign materials, and (5) personal websites. Analysis of variance (ANOVA) suggests that there are statistically significant connections between campaign norms 
and the usage of the different personalised campaign tools..$^{39}$ Therefore, we argue that campaign norms capture personalisation rather well.

However, in order to establish the effect of system change, a few factors have to be controlled for. Control variables include dummies for candidacy features (SMD candidate and Multiple candidacy), incumbency (SMD incumbent), local positions (Local political position ${ }^{40}$ ), party affiliation (Fidesz-KDNP ${ }^{41} M S Z P, J o b b i k,{ }^{42} L M P,{ }^{43}$ and Összefogás ${ }^{44}$ ), perceived Ideological distance between the candidate and the nominating party, candidate selection as perceived by the candidates (Selection by party leadership), and Electoral security. Technical details and descriptive statistics are displayed in the appendix.

To measure the effect of system change, we include time into the model (Election). This variable will absorb all changes happening between the two elections. Nevertheless, we cannot be certain that the changes the time variable causes in personalisation can be attributed solely to the electoral system change. Even if the effect of time points to the expected (positive) direction, additional information is needed to confirm that the change in personalisation can be attributed to the change in the electoral rules. Thus, to interpret the effect of time, we conducted semi-structured interviews with nine campaign experts who took leading roles in organising the 2014 campaigns of Fidesz, KDNP, MSZP, Jobbik, LMP, Együtt 2014, DK, and PM. Interviews were carried out during January and February of 2015. Interviewees were chosen based on their expertise and leadership roles in campaigning: we selected professionals who were able to provide us with relevant information on the different parties' campaign strategies. The selection was not random. We contacted the chief campaign managers of all parties in question to request an interview. In the case they were not available, we asked them to refer us to the next person in the campaign hierarchy, and so on. As a result, we interviewed 5 chief campaign managers, 1 spokesperson, 1 analyst specialised in party campaigns, 1 political adviser, and 1 MP who was a member of the central campaign team. All interview subjects participated in the 2010 campaign as well, thus we could effectively compare the two elections.

\section{Control Variables}

As stated earlier, to show the net effect of time on campaign personalisation, we need to control for variables that presumably influence personalisation. On the basis of the literature on the connection between the electoral formula and personal voteseeking, we expect the campaigns of SMD candidates to be more personalised. Similarly, SMD incumbents are expected to campaign in a more personalised way. They enjoy greater visibility ${ }^{45}$ within their districts than challengers, and they have better access to the local media as well as resources to use campaign tools supporting personalisation. Furthermore, they possess crucial information on constituencyrelated issues that allows them to customise campaign messages.

As to local political positions, it has been argued that voters favour candidates who are connected to the constituency. ${ }^{46}$ Therefore, local politicians are clearly an asset for the party during the elections, because of their potential to gather personal 
vote. However, to achieve this, they have to lead more personalised campaigns, and also sometimes deviate from the party line.$^{47}$ Local offices are not the only positions that may influence the extent of personal vote-seeking. During campaigns, highranking party leaders establish party unity by demonstrating that all the leading officials stand on the same platform. Therefore, it is likely that leaders will focus on party campaigning, maybe with the exception of the candidate for prime minister. ${ }^{48}$ Additionally, personalisation might reflect the candidates' intentions to artificially distance themselves from their parties by focusing more on their own candidacy during their campaign. The greater the distance candidates perceive between them and their parties, the more personalised campaigns are to be expected. ${ }^{49}$

One of the most important factors in the theoretical sense to influence personalisation is candidate selection..$^{50}$ It has already been demonstrated that selection by the national party leaders significantly decreases candidate-orientation in Hungary. ${ }^{51}$ Centralised and exclusive selection strengthens the position of the party against individual candidates, making them less likely to personalise by their own initiative. In our analysis, we control for whether respondents think they were selected by the national party leadership. Moving on, as was pointed out earlier, candidates consider multiple candidacy as a "safety net." Those who are nominated also on lists will most likely not engage in the costly act of personalisation, because the SMD tier is not the only way for them to get elected. Last, but not least, we control for the electoral security of candidates, which we measure as the difference between the candidate's or party list's vote share and the effective electoral threshold. ${ }^{52}$ Negative values indicate that the candidate does not reach the effective threshold, positive values suggest the opposite. Values around zero mark candidates who compete in marginal districts. We anticipate that candidates in marginal districts organise more personalised campaigns compared to both very weak and very strong candidates. To test that the connection between electoral security and personalisation is not linear, we introduce a squared form of security into the model.

\section{Results}

\section{Survey Results}

Working with an unbalanced panel, to be able to capture the effect of time, the random effects (RE) model appears to be the most appropriate choice. ${ }^{53}$ The SarganHansen $^{54}$ test comparing the estimates of the fixed and random effects models indicates that - apart from being more efficient (which is always the case) - the RE estimator also results in consistent models. Table 2 summarises the results.

Looking at Table 2, we see almost all of the "usual suspects" affecting campaign personalisation in the expected way. Not surprisingly, SMD candidacy has the strongest effect on personalisation, which adds an additional proof to the claim ${ }^{55}$ that single-member districts invite personal vote-seeking, whereas candidates in 
Table 2

Random effects Generalised Least Squares model explaining campaign personalisation

\begin{tabular}{lc}
\hline Variables & $B(\mathrm{SE})$ \\
\hline Election: 2014 & $-0.43(0.22)^{*}$ \\
Selection by party leadership & $-0.44(0.21)^{* *}$ \\
SMD candidate & $2.63(0.61)^{* * *}$ \\
SMD incumbent & $0.35(0.31)$ \\
Local political position & $0.44(0.24)^{*}$ \\
National party official & $-0.62(0.36)^{*}$ \\
Ideological distance & $0.03(0.09)$ \\
MSZPa & $1.46(0.60)^{* *}$ \\
Jobbik & $-0.47(0.53)$ \\
LMP & $-1.38(0.69)^{* *}$ \\
Összefogás & $-0.21(0.59)$ \\
Candidacy on multiple tiers & $-0.75(0.41)^{*}$ \\
Electoral security & $1.03(1.51)$ \\
Electoral security^2 & $-7.02(1.89)^{* * *}$ \\
Intercept & $3.51(0.74)^{* * *}$ \\
$n$ & 604 \\
Wald $\chi^{2}$ & 387.76 \\
Sigma_u & 0.84 \\
Sigma_e & 2.09 \\
Rho & 0.14 \\
Within $R^{2}$ & 0.33 \\
Between $R^{2}$ & 0.35 \\
Overall $R^{2}$ & 0.34 \\
\hline
\end{tabular}

Note: Entries are generalised least squares random effects estimates. Standard errors (SEs) are robust and clustered by individual candidates. SMD $=$ single-member districts. Dependent variable: $0=$ partycentred campaign, 10 = candidate-centred campaign .

a.Control group: Fidesz-KDNP.

$* * * \mathrm{p}<0.01,{ }^{* *} \mathrm{p}<0.05,{ }^{*} \mathrm{p}<0.1$

multi-member districts lead more party-centred campaigns in Hungary. SMD candidacy moves respondents 2.63 points toward the candidate-centred end of the scale. Candidate selection does also have a significant effect on personalisation: candidates who think that the national party leadership decided on their candidacy will pursue more party-centred campaigns (by 0.44 units).

As to the effect of the party, we find that MSZP candidates were substantially more candidate-centred than Fidesz candidates. This is hardly a surprise given the unpopularity of the party label during the two elections. Even given that the changes in the electoral rules made the victory of Fidesz more predictable, thus lessening the incentives to engage in the costly business of personalised campaigning, strategists 
Figure 2

The marginal effect of electoral security on campaign personalisation

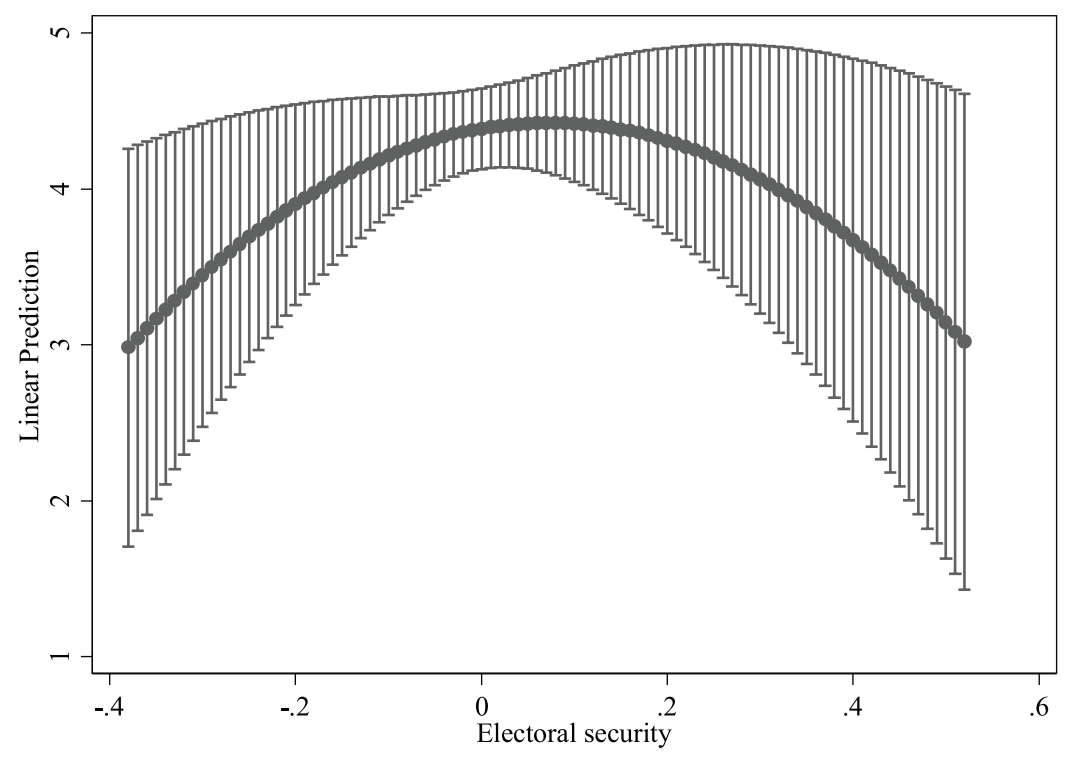

of MSZP opted for more personalisation than Fidesz. Nevertheless, the overall level of personalisation amongst the ranks of MSZP candidates decreased from 2010 to $2014^{56}$ showing how given circumstances made personalisation less appealing in general.

Results also confirm the expectation regarding the non-linear relationship between electoral security and personalisation. Figure 2 visualises how the level of personalisation increases as candidates face fiercer competition (the value of electoral security close to 0 ). Moving from marginal seats (zero) towards secure seats (positive values) and lost causes (negative values) the appeal of personalisation decreases. The expected value of campaign norms at its highest is 4.42, while it decreases to 3 at the two extreme values of electoral security.

Although the effects can only be translated to the sample, SMD incumbents organise more personalised campaigns regardless of whether they are renominated in their SMDs or not. Results also confirm the expected effect of local office holding. Local politicians focus on themselves as candidates to a greater extent than candidates not embedded into local politics.

As for the effect of time, the results do not support our hypothesis. From 2010 to 2014, the value of the dependent variable shifted to the party-centred end by 0.43 points. With all other variable values set to support candidate-centeredness, ${ }^{57}$ candidates take 7.6 in 2014 as opposed to 8 units in 2010. Despite institutional 
changes that should have pushed candidates toward more personalisation, Hungarian candidates chose to move their campaigns in the opposite direction. Given that the electoral system (i.e., electoral tier) is the strongest determinant of personal voteseeking (pointing to the fact that candidates are sensitive to institutional incentives; see Table 2), we must look beyond the survey data to establish what it was that overwrote the supposedly strong positive effect of the electoral system change and why. In the next section, we seek to answer this question. ${ }^{58}$

\section{Interviews}

The interviews were carried out with nine subjects during January and February 2015. They lasted an average of approximately 40 minutes, and covered two main topics. The first part of the interview sought to identify the main aspects of the SMD candidates' campaign strategies. The participants were asked about how much freedom individual candidates had in their campaigns, and to what extent were the candidate selection process and the campaign centralised. In the second part, we focused on the changes between the two elections: how did the parties' relations to personalisation change from the previous election in 2010 to the most recent in 2014. Based on the interviews, we identified three broader topics that are not connected to the electoral system, and that might have negatively influenced the level of personalisation.

Firstly, the interviews confirmed that campaign strategies were controlled by the main party figures in all parties. In some cases, the party centre assessed the candidates' campaign strategies individually and made a decision based on feasibility and compatibility with the central party strategy. Even when the party was less strict about individual campaigns, the majority of the candidates sought the assistance of the party centre. Especially, candidates of small parties transferred the financial resources provided by the state ${ }^{59}$ to the party and received campaign support in the form of flyers and call centre technologies in return. Interviewees listed lack of time, confidence in the party leaders and cost-effectiveness as main reasons behind this. Additionally, due to economies of scale considerations, parties that struggled with a lack of resources chose to focus on the central campaign instead of promoting individual candidates.

Secondly, the change in the number of electoral rounds from two to one led potential coalition partners into unknown territory in 2014. Prior to that, parties did not have to bargain before the elections: every party nominated its own candidate in the SMDs, and electoral results in the first round decided which party withdrew its candidate in favour of the other. Parties just tried to sweat the first round out to see whether they had any chance to win the district alone. Consequently, the first round was about the parties, the second about coalitions. Under the new electoral rules, commitments had to be made prior to the elections, which also affects candidate selection procedures. Furthermore, other changes in the electoral rules such as 
redistricting did not favour small parties; in fact, they forced them to enter into a coalition with other parties prior to the election. The prolonged negotiations ${ }^{60}$ on the fragmented left strongly affected their candidates' opportunities to pursue personoriented campaigns. Összefogás submitted its candidate list at the beginning of February 2014, whereas March 3 was the official deadline for nominations. Thus, candidates simply did not have enough time to develop personalised campaigns. By contrast, other parties like Fidesz and Jobbik finalised their candidate lists at least six months before the elections. Coalition pressure caused additional complications too. Over the course of the negotiations, the focus shifted from the selection of candidates to certain SMDs to the allocation of constituencies among participating parties. Parties had limited control over whether they would get the constituencies where they had locally strong candidates. As a result, in many constituencies parties had to nominate candidates who had neither previous experience nor visibility on the local level. With such a low level of personal vote earning attributes, instead of investing into organising personalised campaigns at short notice, parties leant on the central party campaign in the SMDs.

Thirdly, interviews highlighted that candidate qualities have also a major impact on personalisation in Hungary. Electoral experience, incumbency, and local political background were mentioned as the most important personal vote earning attributes. With regards to electoral experience, in certain parties (DK and Jobbik), candidates who had substantial experience in localised campaigning enjoyed a large amount of freedom to personalise. Conversely, all parties gave less independence for candidates with relatively little experience to take initiative. Parties chose to balance their candidates' limited experience by favouring party campaigning and candidate campaigns were exclusively controlled by the party centre. It seems to be fair to conclude that limited experience leads to party-centred campaigning, while substantial experience results in more personalised campaigns.

Additionally, speaking about candidate qualities, interviewees confirmed that in general, incumbency has a positive effect on personalisation, and SMD incumbents and their challengers usually follow different strategies in their campaigns. They also agreed that the campaigns of incumbent candidates should and do focus more on local peculiarities, and on candidate attributes that might earn personal vote. However, interviews also revealed that Fidesz was quite modest in exploiting the campaign value of its incumbents. As the majority of SMD incumbents were candidates of Fidesz, the effect of incumbency is negligible in our models (see Table 2).

Last but not least, it was implied that candidates who held local political offices at the time of the elections had deviated from the party line and focused more on their own campaigns than candidates not involved in local politics. Given the fact that multiple office-holding was prohibited in 2011, the importance of this finding should not be underestimated. This is especially so as in 2014 many of the local office holders who utilised more personalised campaigns decided to run as candidates at the local elections instead of pursuing national-level legislative careers. Moreover, former 
MPs and candidates who have held political positions, and for whom it was obvious that the local level is more important than national politics, were nominated on party lists and not in SMDs. Therefore, in 2014, candidates with local positions had weaker links to the local level than their counterparts in 2010. Losing many candidates with the willingness and ability to personalise strengthens party-centeredness.

To some extent, the interviews answered the question why Hungarian parliamentary candidates pursue more party-centred campaigns when the rules of the game would support a shift towards candidate-centeredness. Nevertheless, interviewees agreed that without the above political and situational constraints, the changes in the electoral rules would affect the parties' campaign strategies and the candidates' opportunities to pursue personalised campaigns as theorised by the literature. Our subjects admitted that with no changes in the political context, parties would have relied more on candidate image. However, the changing context proved to be a stronger predictor of personalisation than the increasing importance of the SMD tier in getting elected, to which parties adapted by de-emphasising candidates.

\section{Conclusion}

The aim of this article was to capture how recent changes of Hungary's electoral system altered the candidates' personal vote-seeking strategies. Previous studies of the connection between electoral rules and campaign personalisation assume that candidate-centred electoral rules encourage personalisation, while party-centeredness leads candidates to focus on the party. Given the increasing importance of the SMD tier in Hungary's mixed-member electoral system, we might have expected that changes in electoral rules would have a positive effect on campaign personalisation. First, we utilised the data from two consecutive waves of the Comparative Candidates Survey, and modelled campaign personalisation using basic political and electoral variables. To grasp the effect of changes between 2010 and 2014, we also controlled for time. Second, to interpret the coefficient of the time variable, and to determine to what extent the change in the electoral rules played a role in the change in personalisation, we carried out interviews with campaign staff members.

The empirical evidence does not entirely meet the expectation based on the literature. On the one hand, electoral system characteristics, especially the level of candidacy, explain a great deal of campaign personalisation. On the other hand, the overall level of personalisation declined between the two elections. Even SMD candidates pursued less candidate-oriented campaigns in 2014 than in 2010. The interviews revealed that candidates and parties followed party-centred strategies as a result of several party endogenous political factors. First, because of the shortage of resources and costeffectiveness, all parties adopted more centralised campaign organisational strategies. Second, the fragmented left struggled with negotiating a compromise in terms of candidate selection, which left limited time to build up personalised strategies. 
Third, the interviews also highlighted the importance of candidate quality in personalisation. Parties that had enough candidates with proper local or campaign experience left candidates a larger amount of freedom to personalise (DK and Jobbik), compared to parties that could not lean on candidate experience. Furthermore, on account of the ban on multiple office-holding, local politicians who competed in SMDs were prepared to resign from their local level offices. Former MPs and candidates who filled local positions, and perceived defending their local offices as their ultimate goals, were not nominated in SMDs, only on the party lists. Consequently, in 2014, competing local office holders had a weaker connection to the local level than their counterparts in 2010.

The article demonstrates that despite the majoritarian shift in the electoral system, the level of personalisation decreased in Hungary. Situational political constrains and internal factors like candidate quality prohibit parties from exploiting personalised campaigning. Nevertheless, it is important to note that the true effect of the electoral system change is still to be revealed: candidates and parties have just begun the learning process and how they eventually adapt to the new rules is a question for future research. Also, future research will reveal if institutional effects are strong enough to dominate political context effects on the long run. 


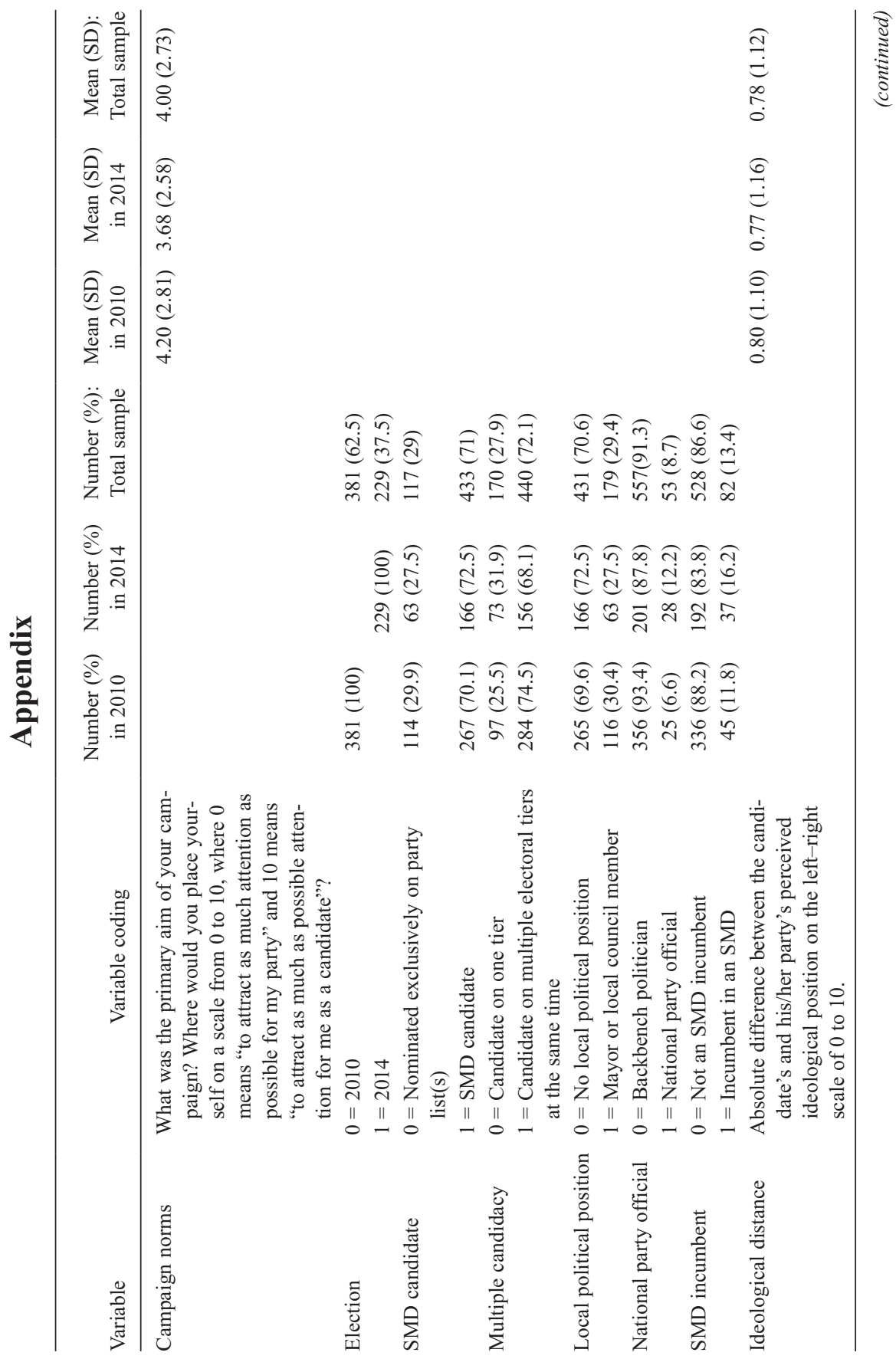




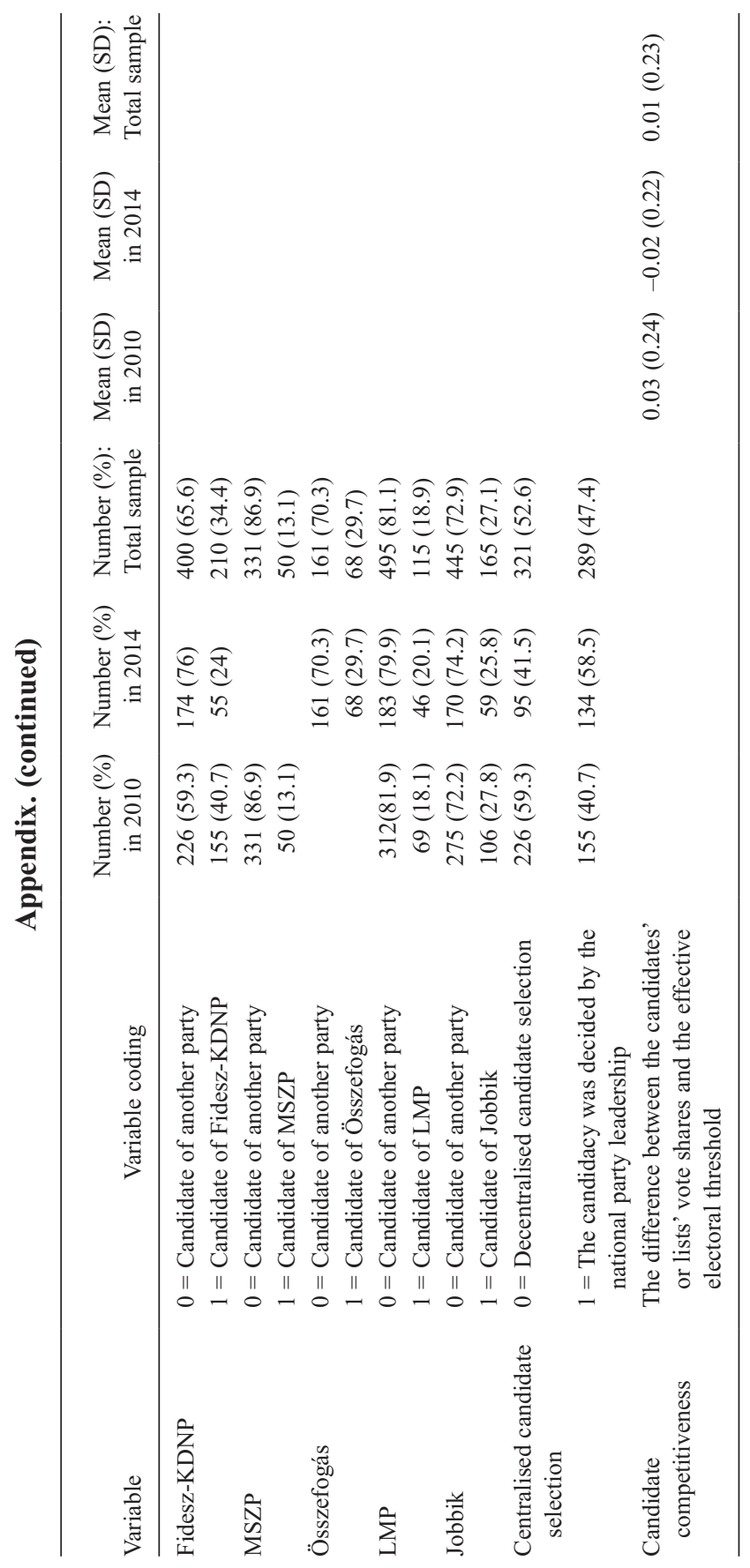




\section{Acknowledgments}

The authors are grateful to Gábor Molnár for research assistance. We would also like to thank Fruzsina Nábelek and Adrienn Tóth for the preparation of the data. As always, all remaining shortcomings are solely the authors' responsibility.

\section{Funding}

Funding Sources: National Research, Development and Innovation Office, (grant number: PD1157471 for Zsófia Papp); János Bolyai Research Scholarship (Zsófia Papp).

\section{Notes}

1. B. Cain, J. Ferejohn, and M. P. Fiorina, The Personal Vote: Constituency Service and Electoral Independence (Cambridge, MA: Harvard University Press, 1987); D. Canache, J. J. Mondak, and E. Cabrera, "Voters and the Personal Vote: A Counterfactual Simulation," Political Research Quarterly 53, no. 3 (2000): 663-76; B. J. Gaines, "The Impersonal Vote? Constituency Service and Incumbency Advantage in British Elections, 1950-92," Legislative Studies Quarterly 23, no. 2 (1998): 167-95; R. Herrera and M. Yawn, "The Emergence of the Personal Vote," The Journal of Politics 61, no. 1 (1999): 136-50; J. J. Mondak, "Competence, Integrity, and the Electoral Success of Congressional Incumbents," The Journal of Politics 57, no. 4 (1995): 1043-69; P. Norton and D. Wood, "Constituency Service by Members of Parliament: Does It Contribute to a Personal Vote?," Parliamentary Affairs 43, no. 2 (1990): 196-208; S. M. Swindle, "The Supply and Demand of the Personal Vote Theoretical Considerations and Empirical Implications of Collective Electoral Incentives," Party Politics 8, no. 3 (2002): 279-300.

2. Cain et al., Personal Vote.

3. J. M. Carey and M. S. Shugart, "Incentives to Cultivate a Personal Vote: A Rank Ordering of Electoral Formulas," Electoral Studies 14, no. 4 (1995): 417-39.

4. Cain et al., Personal Vote; T. D. Lancaster, "Electoral Structures and Pork Barrel Politics," International Political Science Review 7, no. 1 (1986): 67-81; T. D. Lancaster and W. D. Patterson, “Comparative Pork Barrel Politics," Comparative Political Studies 22, no. 4 (1990): 458-77; P. Norris, "The Twilight of Westminster? Electoral Reform and Its Consequences," Political Studies 49, no. 5 (2000): 877-900; E. L. Scholl, "The Electoral System and Constituency-Oriented Activity in the European Parliament," International Studies Quarterly 30, no. 3 (1986): 315-32.

5. J. Curtice and P. Shively, "Who Represents Us Best? One Member or Many?," in The Comparative Study of Electoral Systems, ed. H.-D. Klingemann (Oxford: Oxford University Press, 2009); M. Gallagher and I. Holliday, "Electoral Systems, Representational Roles and Legislator Behaviour: Evidence from Hong Kong," New Zealand Journal of Asian Studies 5, no. 1 (2003): 107-20; V. Heitshusen, G. Young, and D. M. Wood, "Electoral Context and MP Constituency Focus in Australia, Canada, Ireland, New Zealand, and the United Kingdom," American Journal of Political Science 49, no. 1 (2005): 32-45; S. Morgenstern and S. M. Swindle, “Are Politics Local?," Comparative Political Studies 38, no. 2 (2005): $143-70$.

6. Carey and Shugart, "Incentives to Cultivate a Personal Vote"; M. S. Shugart, M. E. Valdini, and K. Suominen, "Looking for Locals: Voter Information Demands and Personal Vote-Earning Attributes of Legislators under Proportional Representation," American Journal of Political Science 49, no. 2 (2005): 437-49.

7. M. Chiru, "Cheap Talk or Proper Signaling? Styles of Campaigning and Engagement in Constituency Service," Social Science Quarterly (2017); T. Zittel, "Constituency Candidates in 
Comparative Perspective-How Personalized Are Constituency Campaigns, Why, and Does It Matter?," Electoral Studies 39 (2015): 286-94.

8. J. Fearon, "Electoral Accountability and the Control of Politicians: Selecting Good Types versus Sanctioning Poor Performance," Democracy, Accountability, and Representation, ed. A. Przeworski, S. C. Stokes, and B. Manin (New York: Cambridge University Press, 1999).

9. A. André, A. Freire, and Z. Papp,"Electoral Rules and Legislators' Personal Vote-Seeking," Representing the People: A Survey among Members of Statewide and Substate Parliaments, ed. Sam Depauw and Kris Deschouwer (Oxford: Oxford University Press, 2014), 87-109; W. Cross and L. Young, "Personalization of Campaigns in an SMP System: The Canadian Case," Electoral Studies (2014), online version; N. Eder, M. Jenny, and W. C. Müller, "Winning over Voters or Fighting Party Comrades? Personalized Constituency Campaigning in Austria," Electoral Studies (2014), online version; T. Gschwend and T. Zittel, "Do Constituency Candidates Matter in German Federal Elections? The Personal Vote as an Interactive Process," Electoral Studies 39 (2015): 338-49; C. Holtz-Bacha and G. Mazzoleni, The Politics of Representation: Election Campaigning and Proportional Representation (New York: Peter Lang, 2004); H. Kriesi, "Personalization of National Election Campaigns," Party Politics 18, no. 6 (2012): 825-44; P. Selb and G. Lutz, "Lone Fighters: Intraparty Competition, Interparty Competition, and Candidates' Vote Seeking Efforts in Open-Ballot PR Elections," Electoral Studies (2014), online version; T. Zittel, "Constituency Candidates in Comparative Perspective-How Personalized Are Constituency Campaigns, Why, and Does It Matter?," Electoral Studies (2015), online version; T. Zittel and T. Gschwend, "Individualised Constituency Campaigns in Mixed-Member Electoral Systems: Candidates in the 2005 German Elections," West European Politics 31, no. 5 (2008): 978-1003.

10. Carey and Shugart, "Incentives to Cultivate a Personal Vote."

11. Lancaster, "Electoral Structures"; Norris, "The Twilight of Westminster?"; Scholl, "The Electoral System."

12. Heitshusen et al., "Electoral Context."

13. Norris, "The Twilight of Westminster?"

14. Curtice and Shively, "Who Represents Us Best?"

15. N. Atmor, R. Y. Hazan, and G. Rahat, "Candidate Selection," in Personal Representation: The Neglected Dimension of Electoral Systems, ed. J. M. Colomer (Colchester: ECPR Press, 2011), 21-36; Carey and Shugart, "Incentives to Cultivate a Personal Vote"; P. Mitchell, "Voters and Their Representatives: Electoral Institutions and Delegation in Parliamentary Democracies," European Journal of Political Research 37, no. 3 (2000): 335-51; P. Norris, Electoral Engineering: Voting Rules and Political Behavior (Cambridge: Cambridge University Press, 2004).

16. Atmor et al., "Candidate Selection."

17. At both elections under investigation, Fidesz-KDNP had the most chance of winning in the SMDs. According to Mihályffy, Fidesz candidates were handpicked by a small group of national party leaders. Z. Mihályffy, "Kampány óvatosan - A Fidesz 2010. évi országgyülési választási kampánya," Kritikus kampány. A 2010-es országgyülési választási kampány elemzése, ed. G. Szabó, Z. Mihályffy, and B. Kiss (Budapest: L'Harmattan, 2011), 24-47.

18. Carey and Shugart, "Incentives to Cultivate a Personal Vote."

19. Cain et al., Personal Vote.

20. Curtice and Shively, "Who Represents Us Best?"; and Gallagher and Holliday, "Electoral Systems."

21. Z. Papp and B. Zorigt, "Party-Directed Personalisation: The Role of Candidate Selection in Campaign Personalisation in Hungary," East European Politics 32, no. 4 (2016): 466-86.

22. M. S. Shugart and M. P. Wattenberg, "Introduction: The Electoral Reform of the Twenty-First Century?," in Mixed-Member Electoral Systems. The Best of Both Worlds?, ed. M. S. Shugart and M. P. Wattenberg (Oxford: Oxford University Press, 2001).

23. First, the electoral threshold was raised from 4 to 5 per cent to prevent excess fragmentation. Second, while legislators were not allowed to be mayors during the first electoral term, the ban on multiple office-holding was lifted in 1994. 
24. C. Nikolenyi, "When Electoral Reform Fails: The Stability of Proportional Representation in PostCommunist Democracies," West European Politics 34, no. 3 (2011): 607-25.

25 . With regards to the two elections under investigation, it was very clear who the prospective winners and losers were. There was no doubt that Fidesz-KDNP would harvest the constituencies. Thus, before the elections, parties had a very clear idea of whether they would be winners or losers. As vote-maximizing agents, they could build their strategies along these perceptions.

26. Hungarian Socialist Party (Magyar Szocialista Párt, MSZP).

27. Alliance of Free Democrats-The Hungarian Liberal Party (Szabad Demokraták Szövetsége, SZDSZ).

28. Fidesz-Hungarian Civic Alliance (Fidesz-Magyar Polgári Szövetség).

29. G. Tóka and S. Popa, "Hungary," in The Handbook of Political Change in Eastern Europe, ed. Sten Berglund, Joakim Ekman, Kevin Deegan-Krause, and Terje Knutsen (Cheltenham, UK: Edward Elgar, 2013), 291-338.

30. http://index.hu/belfold/2010/valasztas/szelesre_nyilt_ollo_az_mszp_es_a_fidesz_kozott/ (accessed 1 June 2017).

31. https://mno.hu/belfold/valasztas-elotti-kutatasok-senki-ne-gondolja-hogy-eldolt-1219646 (accessed 12 June 2017).

32. https://blogs.reading.ac.uk/readingpolitics/2011/12/26/hungary $\% \mathrm{E} 2 \% 80 \% 99 \mathrm{~s}$-new-electoral-lawpart-2-analysis/ (accessed 12 June 2017); http://hazaeshaladas.blog.hu/2011/11/25/tul_a_demokracian_az_ uj_orszaggyulesi_valasztasi_rendszer_modellje_2_resz (accessed 12 June 2017); https://krugman.blogs. nytimes.com/2014/02/28/hungary-an-election-in-question-part-2/?mcubz=2 (accessed 12 June 2017).

33. Non-resident citizens are allowed to vote for the national party lists. This change is claimed to help Fidesz, as the majority of politically active citizens living in neighbouring countries are very likely to be voters of Fidesz.

34. The two waves received 381 and 229 valid responses respectively. Note that we only report cases that have no missing values along variables incorporated into the analysis.

35. In 2010, a total of 2,584 candidates competed for 386 seats, while in 2014 the number of candidates was 3,348 for 199 parliamentary mandates.

36. As to the representativeness of the sample, the subsample of legislators in both waves is representative across both mandate type and party affiliation. The candidate subsample underrepresents Fidesz and slightly overrepresents other parties. This may cause a problem because candidates of parties other than Fidesz are expected to be more candidate-centred, pushing the effect of the hypothesised (candidatecentred) direction. Nevertheless, given our results presented in Table 2, even this effect is not large enough to make our hypothesis true.

37. Zittel and Gschwend, "Individualised Constituency Campaigns."

38. Kernels can be best described as histograms which are smooth and that are not dependent on the choice of origin. The data is divided into intervals, just as in the case of histograms, and the density of the centre of these intervals is displayed. The main difference is that in kernels, intervals are allowed to overlap, which makes the density distribution look smoother. For the figure, the Epanechnikov kernel function was used.

39. $F$ statistics from analysis of variance for both waves of data collection: personal campaign posters (2010: $F=77.816,2014: F=46.473)$, newspaper ads $(2010: F=40.744,2014: F=40.720)$, spots in radio/TV/cinemas (2010: $F=38.377,2014: F=7.433$ ), flyers or other (give-away) campaign materials (2010: $F=42.718,2014: F=40.720)$, website $(2010: F=31.662,2014: F=8.224)$. All relationships are significant at a 5 per cent level.

40. From 2014 on, legislators are not allowed to fill any local office. However, they can still be nominated at the national elections. They only have to decide which position they want to keep after the elections. Thus, also in 2014, many candidates fill local political positions at the time of the election.

41. Fidesz-Hungarian Civic Alliance (Fidesz-Magyar Polgári Szövetség) and Christian Democratic People's Party (Kereszténydemokrata Néppárt). There is no reason to treat the governing coalition as separate parties, as all their candidates and party lists are joint. 
42. Jobbik, the Movement for a Better Hungary (Jobbik Magyarországért Mozgalom).

43. Politics Can be Different! (Lehet Más a Politika!, LMP)

44. Unity (Összefogás) included: MSZP, Together 2014 (Együtt 2014), Democratic Coalition (Demokratikus Koalíció, DK), Dialogue for Hungary (Párbeszéd Magyarországért, PM), Hungarian Liberal Party (Magyar Liberális Párt, MLP). The alliance was formed for the 2014 election. In our model, only MSZP will be controlled for separately, because other parties did not have candidates both at the 2010 and the 2014 elections. As we control for not only fixed but also random effects, we include a control variable for MSZP candidates to see the effect of the former leading party of the left. Although the other members of Összefogás have distinct characteristics too, unfortunately, their effect can only be taken into account assessing the interview data.

45. Zittel and Gschwend, "Individualised Constituency Campaigns."

46. R. D. Putnam, The Comparative Studies of Political Elites (Englewood Cliffs, NJ: Prentice-Hall, 1976); Shugart et al., "Looking for Locals"; M. Tavits, "Effect of Local Ties on Electoral Success and Parliamentary Behaviour: The Case of Estonia," Party Politics 16, no. 2 (2010): 215-35.

47. J. Dewogheraele, R. M. Berton, and J. Navarro, "Cumul de Mandats" in Contemporary French Politics. An Empirical Study of the XIIe legislature of the Assemblée Nationale, 2008 [online], http:// halshs.archives-ouvertes.fr/docs/00/12/79/06/PDF/_Cumul_des_Mandats_in_Contemporary_French_ Politics.pdf; Tavits, "Effect of Local Ties."

48. The literature on the presidentialisation of politics (T. Poguntke and P. Webb, "The Presidentialization of Politics in Democratic Societies: A Framework for Analysis," The Presidentialization of Politics. A Comparative Study of Modern Democracies, ed. T. Poguntke and P. Webb [Oxford: Oxford University Press, 2005]) suggests that in the case of candidates for prime minister, personalisation is expected to be at higher levels.

49. Zittel and Gschwend, "Individualised Constituency Campaigns."

50. Atmor et al., "Candidate Selection"; Cross and Young, "Personalization of Campaigns."

51. Papp and Zorigt, "Party-Directed Personalisation."

52. $\frac{0.75}{\mathrm{M}+1}$ (A. Lijphart, Patterns of Democracy: Government Forms and Performance in Thirty-six Countries [New Haven, CT: Yale University Press, 1999]). See S. Olivella and M. Tavits, "Legislative

Effects of Electoral Mandates," British Journal of Political Science 44, no. 2 (2014).

53. A. C. Cameron and P. K. Trivedi, Microeconometrics Using Stata, 1st ed. (College Station, TX: Stata Press, 2009).

54. Regarding each model presented in this article, the null hypothesis of the test cannot be rejected.

55. M. Chiru, "Multiple Candidacies and the Role of the Lowest Electoral Tier for Individualized Campaigning," East European Politics \& Societies (2015), 0888325415569761; Z. Papp, "CampaignPersonalization and Constituency Focus in a Mixed-Member Electoral System. The Case of Hungary," World Political Science 11, no. 1 (2015): 75-95.

56. The average value of the dependent variable significantly $(F=7.3)$ decreased from 6.1 to 4.5 in the case of the MSZP candidate.

57. SMD candidate, holds local political office, backbench, SMD incumbent, average ideological distance and electoral security, MSZP candidate, decentralised candidate selection, and single-tier candidate.

58. We tested the robustness of our results by running the regression of Table 2 on a matched data set. Matching techniques aim at creating one of the key benefits of randomized experiments for estimating causal effects, namely, that both the treatment and the control "guaranteed to be only randomly different from one another on all background covariates" (E. A. Stuart, "Matching Methods for Causal Inference: A Review and a Look Forward," Statistical Science 25, no. 1 [2010]: 1-21, 1). This seems needed, as the electoral reform may have affected the candidate pool itself, especially as it prohibits multiple office holding. We used coarsened exact matching (CEM) to create the matched data set (M. Blackwell, S. Iacus, G. King, and G. Porro, “CEM: Coarsened Exact Matching in Stata,” The Stata Journal 9 [2009]: 524-46). 
Pre-treatment variables were SMD candidacy, party leadership, SMD incumbency, ideological distance from the party, party affiliation, the candidate selection method, and electoral security. The new model returns a coefficient of $-0.54(\mathrm{SE}=0.25)$ significant at the 5 per cent level. We decided to keep the original random effects generalised least squares model, because the results obtained after running the model after the CEM procedure are heavily dependent upon which variables we use as pretreatment factors. Additionally, importance weighting does not work with models applying cluster robust standard errors, which we think are essential because of the panel nature of the data. Furthermore, crucial variables, such as party affiliation, cannot be controlled for because of the party coalitions at the 2014 election (there is no match for the coalition in the 2010 data set). The effect of election is negative in all models (original and matched), which speaks against our hypothesis based on the effects of electoral rules.

59. Individual candidates of parties that were able to nominate at least twenty-seven SMD candidates received 1 million HUF to cover campaign expenses. Candidates might choose to give the subsidy to their parties.

60. After several months of talks, the left-wing opposition parties reached an agreement in 14 January 2014 to run as a grand alliance for the 2014 parliamentary elections. Two parties (MSZP and Együtt 2014) began negotiations and the other three parties joined in only later. The negotiations were excessively long, because firstly, the initial two parties had difficulties agreeing which other parties should be involved in the alliance, and secondly, they had very distinct preferences in regard to campaign policies.

Zsófia Papp is Research Fellow at the Centre for Social Sciences, Hungarian Academy of Sciences. She received her PhD in Political Science at Corvinus University of Budapest where she teaches courses in political science and research methodology, and serves as a thesis supervisor. She publishes on campaign personalisation and legislator behaviour.

Burtejin Zorigt is a PhD Candidate at the Department of Political Science at Central European University in Hungary. Her doctoral dissertation examines the effect of candidate selection procedures on women's descriptive representation. Her research interests include gender and politics and comparative politics with a particular focus on parliamentarians and political parties. 